\title{
Internationalisation of pension funds: Incentives and future patterns
}

Received: 4th May, 2005

\begin{abstract}
Alfred Slager
is Project Manager at PGGM Investments, the Dutch pension fund for the healthcare sector, and is an assistant professor at the Rotterdam School of Management. His research interests focus on pension funds, asset management and (international) banking strategies. Between 1995 and 2000 he worked for KBW Wesselius Effectenbank, part of the Fortis group, where he held different positions in private banking and asset management.
\end{abstract}

\section{Peter Kraneveld}

is Special Advisor for International Affairs to the Chairman of PGGM. His previous positions include those of Chief Economist at PGGM, Principal Administrator at the Organisation for Economic Cooperation and Development (OECD) in Paris and officer at the Dutch Ministry of Economic Affairs.

\begin{abstract}
This paper aims to explore the incentives for pension funds to internationalise within the European Union. It reviews a theoretical framework from international business and banking literature and applies this to the internationalisation of pension funds. Finally, an assessment about the future path of pension fund internationalisation is made.
\end{abstract}

Keywords: cross-border pension provision; internationalisation; objectives; asset management; European Union

\section{Introduction}

Financial integration in the European market is progressing at varying degrees. Concentration in the securities and investment banking market has taken place since the end of the 1980s. A significant part of the asset management market coalesced around the Undertakings for Collective Investments in Transferable Securities (UCITS) directive in 1985, enabling investments funds established in one member state to be marketed in another state.

Commercial banks and insurance companies had a major boost with the Second European Banking Directive in 1992. In 2003, the European Union (EU) adopted Directive 2003/41 (the IORP Directive $\left.{ }^{1}\right)$. This creates a
European passport for pension funds and sets the conditions to be fulfilled to obtain it. The Directive also lays down some basic principles including the prudent person principle for investments. This principle gives considerable freedom of investment, but also considerable responsibility to pension fund governors. The stage is therefore set for internationalisation of pension funds within the EU.

Yet problems remain. The most obvious one is the different tax treatment of pension money flows. While a large majority of member states taxes only pension payment, not investment results or contribution payments, some do tax investment results and a few will tax contribution payments, rather than 
pension payments. In addition, a majority of member states discriminate between payments to or from domestic and foreign pension funds. The former issue is addressed with Commission communication COM(2001)214. This expresses a preference for the majority system. The latter issue is sure to disappear, albeit slowly, as the European Court of Justice does not allow such discrimination. $^{2}$

The Directive must be implemented before 23rd September, 2005. Its effects are far from certain, but the policy objectives of the Union are clear. Starting from the notions of free movements of persons and the free movement of services, the EU wants to create a community-wide market for financial services. Cross-border pension funds are part of this goal. Therefore, even if Directive 2003/41 does not accomplish a Union-wide pensions market, follow-up measures, eg in the areas of taxation, accountancy, pension portability and supervision are to be expected.

The private sector has become interested in internationalisaing pension funds for the sake of lowering costs, increasing returns and providing streamlined employee benefits across borders. These arguments are tailored for large multinational enterprises running their own pension schemes. The solution is asset pooling: creating a vehicle in one country that enjoys full tax transparency in others and can therefore be used as the legal envelope of an international pension fund. Luxembourg and Ireland responded with specialised contracts and started negotiations with other countries to obtain tax transparency (Luxembourg was slightly more successful in the number of bilateral agreements it negotiated.) Both countries secured an informal agreement with the USA. Unilever is contemplating setting up a pooled fund in Luxembourg.
IBM has stated that it wants to relocate its British pension fund to Ireland. Several other enterprises are thought to harbour similar intentions. ${ }^{3}$

While asset pooling and international pension funds are of economic interest to company pension funds, they can also be of use to sector pension funds. A transparent EU-wide pension market will lead to arbitraging possibilities between funds in member states with the lowest cost supervisory structure. A major item in these costs is the supervisors' solvency requirements. These vary widely. While pension funds will want a serious system of supervision to inspire confidence among their participants, they do not necessarily agree with some of the more extreme provisions on financial reserves imposed on them. ${ }^{4}$ If funds start to become concentrated in certain member states, the other states will react, but their options will be limited to closer cooperation and coordination of requirements. This would make emigration for reasons other than supervision arbitration easier.

Furthermore, the EU is working on a directive on pension portability.

Publication of the first draft has already been delayed a number of times and the procedure for acceptance, which under the present rules calls for consensus among EU member states, may well be long and arduous. The goal of pension portability is so central to the basic EU policy target of freedom of movement for persons that it is hard to see the that it will not come about.

In short, the harmonisation and portability of pensions throughout Europe is greatly stimulated, and major barriers to the internationalisation of pension funds are removed. How will this internationalisation progress? This paper reviews existing banking and international business literature and applies this to pension funds. Two 
research questions will be investigated: what are the motives for internationalisation, and what organisational forms of internationalisation might be pursued? This paper identifies those functions of a pension fund that will probably remain domestic and those that are sensitive to internationalisation. It identifies motives and different stages and organisational forms of internationalisation, and speculates on likely future approaches.

\section{Why and how do pension funds internationalise?}

Internationalisation of pension fund management activities is a strong structural force. ${ }^{5}$ Reasons are the progressing ageing population, requiring increased replacement by pay-as-you-go systems by full funding. The necessary skills for fund management need not be located in the domestic market. For example, the increased focus on equity investments builds on expertise that is concentrated in the USA and the UK. In addition, the expertise on defined contribution (DC) systems is concentrated in the USA. Also, the pension fund structure might not be optimal in the home country from a taxation perspective, with other countries allowing for more efficient tax regimes.

Compared with internationalisation literature on banks, there is relatively little literature on why pension funds internationalise. This is not surprising since it is a relatively new development spurred by new EU regulation. We have to borrow from related research for international business and for financial services firms, eg insurance companies or banks. The internationalisation of banks has received the most research attention over the years. The applicability of banking literature for pension funds can be justified on the basis that pension funds and banks are both financial services providers and share similar processes such as funding, asset transformation and distribution. Also, it can be argued that the incentives and framework for the internationalisation of pension funds show a close resemblance to those for banks: increasing focus on costs, a trend toward deregulation and an awareness that besides one's position in the domestic market, the future relative position in an integrated European market should also be a strategic consideration. $^{6}$

To fill this gap, we apply the models of Canals and Dunning to the internationalisation of pension funds. Canals investigated internationalisation strategies of banks and presented an internationalisation model which is based on three main incentives (scale, customer service and resources), the combination of which he hypothesises to be instrumental for the internationalisation of banks. ${ }^{7}$ Applying this model to pension funds, scale, customer service and resource transfer would be the main motives for international activity.

When increasing scale, pension funds expect that size generates more revenues by lowering costs. Increasing investment in technology can only be recouped by larger scale. Also, scale provides some protection for a financial institution from becoming a target for a hostile takeover. Estimates for a minimum efficient asset management scale vary. Broby argued that the minimum efficient scale for fund management was around $€ 7$ bn in $2002{ }^{8}$ A McKinsey study showed that large firms in Europe have a 25 per cent cost advantage in relation to assets, mostly support, back and middle office costs. ${ }^{9}$ Since then observers agree that costs, particulary compliance costs, have only increased further. ${ }^{10}$ Heinemann estimated that if European funds were the same average size as in the USA, around $€ 5 b n$ would be saved annually. ${ }^{11}$ 
Providing more and better customer service might also be relevant. For example, if the pension fund's customers relocate outside the home country, a pension fund might offer the same quality of service to its customers abroad. Alternatively, they could enter markets with a lower degree of financial innovation to offer services that national pension funds do not. Pension funds can also transfer physical and/or intangible resources or skills from headquarters or a unit in one country to another (such as financial resources, technology, branding, management skills).

Internationalisation of pension funds may also be a strategic response to foreign pension fund entry. Internationalisation will gradually lead to large average fund sizes that should produce cost savings. In the short term, the presence of these foreign asset management groups in other markets should increase competitive pressure and force all competing companies to apply stricter cost controls, increasing the incentives for other pension funds to internationalise. $^{11}$

Dunning has published extensively on the internationalisation of firms, developing a general framework for determining the extent and pattern of foreign owned activities undertaken by domestic firms and also domestic activities owned by foreign firms. Dunning identified four different types of foreign-based investments: market seeking, resource seeking, efficiency seeking and strategic asset seeking investments. ${ }^{12}$ The authors will adapt his classification for pension funds and suggest the most likely form for setting up this type of activity.

1 Market seeking investments satisfy a particular foreign market, or set of foreign markets. The markets are new, not the services - they are merely adapted to local customs and tastes. A bank may consider it necessary to have a physical presence in the leading markets serviced by its competitors.

An example is ING/Nationale Nederlanden, which in 1989 acquired ING Bank Slaski, ${ }^{13}$ which includes a Polish pension fund that is among the country's largest. ${ }^{14}$

2 A pension fund invests abroad to seek resources at a lower real cost than could be obtained in the home market. Or the pension fund wants to invest abroad to acquire specific resources that cannot be obtained at the home market. The motivation for the investment is to make the investing pension fund more profitable and competitive in the markets it serves or intends to serve. Activities are concentrated in financial centres outside the home country such as investment banking or securities distribution or in administrative (offshore) centres, to outsource administrative services or relocate administrative services. An example is ABP Pension fund, which established offices in Singapore and New York for some of its investment activities.

3 Investments designed to create a more efficient division of labour or specialisation of an existing portfolio of foreign and domestic activities are efficiency seeking investments. The pension fund rationalises its organisational structure in such a way that it can benefit from common governance of these multinational activities, either through economies of scale and scope or through tax arbitraging. The pension fund aims to reap rewards from the resulting economies of scale and scope, enhanced by risk diversification. In order for efficiency seeking strategies to take place, cross-border markets must be both well developed and 
Table 1 Functions of a second pillar pension fund and its foreign direct investment types

\begin{tabular}{lllll}
\hline & $\begin{array}{l}\text { Market } \\
\text { seeking }\end{array}$ & $\begin{array}{l}\text { Resource } \\
\text { seeking }\end{array}$ & $\begin{array}{l}\text { Efficiency } \\
\text { seeking }\end{array}$ & $\begin{array}{l}\text { Strategic asset } \\
\text { seeking }\end{array}$ \\
\hline $\begin{array}{l}\text { Fiduciary of the pension scheme } \\
\text { Client servicing }\end{array}$ & C & C & N/A & N/A \\
$\begin{array}{l}\text { Pension administration } \\
\text { Asset management }\end{array}$ & C & C, S & C, S & C, S \\
\hline
\end{tabular}

Note: NA: Not applicable, S: possible leading motive for sector pension funds, C: possible leading motive for corporate pension funds

open. This strategy should then flourish in regionally integrated markets. Consultant firm Deloitte has launched a pension-pooling offering in 2004 and is working with consumer products group Unilever on implementing pooling in practice. ${ }^{3}$

A possible consequence of either resource seeking or efficiency-seeking strategies is that the foreign investment supports activities of the domestic pension fund. Such activities need not be self-contained profit centres. This could be the case in the start up phase of the market-seeking activity, where foreign units have to be set, without a clear profit goal in sight. Alternatively, the pension funds set up back office activities outside the country where the activity is located. Here, asset pooling is the farthest developed: a multinational corporate pension fund can have a fully funded pension fund in a foreign country, but no physical assets located there.

4 Strategic asset-seeking investments augment or protect the specific competitive advantages of the investing pension fund, or seek to reduce those of its competitors. The exploitation of cost advantages to scale or market specific advantages over competitors are the lesser motive. Acquisitions, increase in asset growth and/or market share are important indicators for a strategic asset-seeking strategy.

An alternative to outright acquisitions is financial participations in other pension funds. Besides gaining from dividends and capital appreciation, added benefits are more inside information into the shareholding as a result of shareholder rights. This might speed up learning curve of the pension fund in this (new) activity or country, and create an advantage when opting for full acquisition.

These strategic investments options cannot be applied to pension funds in general; we have to differentiate between the functions a pension fund has. The discussion identifies three basic functions for a pension fund: fiduciary of the pension scheme, pension administration and asset management. Table 1 shows the relevance of the strategic investment types for the different functions. Asset management activities are more likely to be exposed to the different strategic investments options, while servicing or acquiring clients is also a major impetus. Actually relocating pension schemes is relevant for corporate pension funds, but may be less so for public sector funds due to their being intertwined with domestic regulation and institutions.

The four different types of foreign direct investments suggest a current separation in internationalisation. Sector pension funds are typically engaged, or consider engaging in, resource-based internationalisation, arbitraging between different regulatory systems. Corporate pension funds arbitrage between regulatory systems as well as restructuring for cost savings. Finally, commercial pension fund providers use 
internationalisation for market seeking purposes, gaining market share in new countries in the EU. The scale of foreign direct investments for corporate and sector funds are bound to be modest compared to commercial pension fund providers or insurers. In general, their capital base is directly related to the pension scheme(s) they serve. Sector and corporate pension funds also do not attract external funding from the capital market (although this is not entirely unfeasible). This implies that their investments will be relatively limited in size, and that larger foreign activities will take the shape of alliances or mutual financial participation constructions.

\section{Barriers to internationalisation}

Despite the gradual removal of barriers to rationalisation, and the rationale for the four foreign investment patterns outlined, four arguments remain against internationalisation that can be grouped around a home bias theme. These are cultural differences in savings and investment patterns, structural differences in the pension premiums paid, political choice and differences in individual investors' risk aversion.

1 Cultural differences in savings and investment patterns exist that cannot be attributed to demographic and/or liability based characteristics of the pensioners. Pension funds in, for example, the UK tend to have a higher risk appetite compared to its continental partners. Individuals may have a completely different risk appetite, however, which could be satisfied only by foreign pension funds.

2 Structural differences in the average pension premium paid per country exist. This could be interpreted as a home bias. For example, the defined benefit (DB) systems in the EU are in essence alike, but while the British tend to contribute not more than 10 per cent of their salary, the Dutch accept a premium of up to 25 per cent. These differences cannot be attributed to menu costs in switching from one pension system to another. Such differences may attract individuals, who aim for a different pension deal than the mainstream available in their own country, but the vast majority of beneficiaries will resist a pension promise that is very different from what they know, no matter how efficient it would be.

3 Political choice plays an important role. A country's body politic may be more state orientated or more market orientated. It may put more weight on political dogma or on efficiency. For instance, Dutch pension funds are established and governed by both employees and employers, while in most other countries they are mainly organised by employers. Sweden offers investment choice to pension fund participants, a plan with similar characteristics as the American 401(k) plans. ${ }^{15}$ In this field also, it is hard to see political preferences and choices converging for the sake of economic efficiency, unless underlying market forces change significantly.

4 There is a trend to develop DC pensions that require people to exercise individual choice. The experience of poor stock market performance, provider failure, counter-intuitive decisions by regulators and means-testing have frightened people away from voluntary participation in private pension schemes. These negative experiences can be contagious. ${ }^{16}$ In other words, lagging performance on capital markets will reduce the incentive to internationalise.

5 Past patterns in other financial services 
mergers suggest that domestic mergers and consolidation might precede an increase in internationalisation patterns. This can be attributed to the importance regulators attach to strong domestic financial institutions, and also the preference of institutions to merge with their domestic counterparts reducing language, institutional and cultural barriers compared to foreign institutions. ${ }^{17}$ Consolidation and restructuring stages in the European pension market may still be a long way off. Domestic consolidation as a preparatory step for internationalisation is quite feasible, however, it is in line with the experience of bank internationalisation, as well as current trends observed with some pension funds. Consolidation for pension funds takes on a different shape than for insurers or banks: the pension fund as fiduciary manager remains independent and located in the home country but its 'physical activities' (eg client servicing, pension administration and asset management, see Table 1) will be outsourced to, and increasingly concentrated with, a selected group of (domestic or foreign) pension funds and service providers. After a period of domestic consolidation, internationalisation of pension funds may increase its pace in financial markets.

\section{Future paths of internationalisation}

A long-standing research debate is whether the modes of internationalisation are sequential. Once a pension fund has set up an international activity, it will acquire experiential knowledge of the foreign market, and gradually increase its (long-term) capital commitment, shifting from self-established subsidiaries and financial participations to joint ventures and acquisitions. Nowadays, the flexibility of organisational modes, the costs of establishing such activities and the technologies needed, allow more variations in steps toward increased internationalisation. Some stylised observations might be useful to position the strategic investment patterns (market seeking, resource seeking, efficiency seeking, strategic asset seeking) over time, however. Four stages of internationalisation for banks (and financial services in general) can be identified, differing in the degree of involvement and long-term commitment: entry, expansion, consolidation and restructuring. ${ }^{6}$ These stages combine the strategic motives to internationalise, as well as the organisational forms that are most suited to accommodate this stage.

After years of buoyant growth, the asset management industry itself is currently undergoing a process of consolidation and restructuring. Pension funds on the other hand are in the first stages of entry and/or expansion.

\section{The entry phase}

In this phase, the learning and cost curve for the pension sector is bound to be initially restricted to the largest corporate and sector pension funds. The advantages of entering into a pooling agreement must be weighed against the costs. These are particularly high at the moment because there is practically no experience with, or jurisprudence about, asset pooling. As more asset pooling contracts are concluded these costs and uncertainties will diminish greatly. Other pension funds can follow suit, benefiting from the lower set-up costs. Resource seeking, and market seeking are likely objectives in this stage.

The creation of new pension funds, or the acquisition and restructuring of existing ones is more likely in countries 


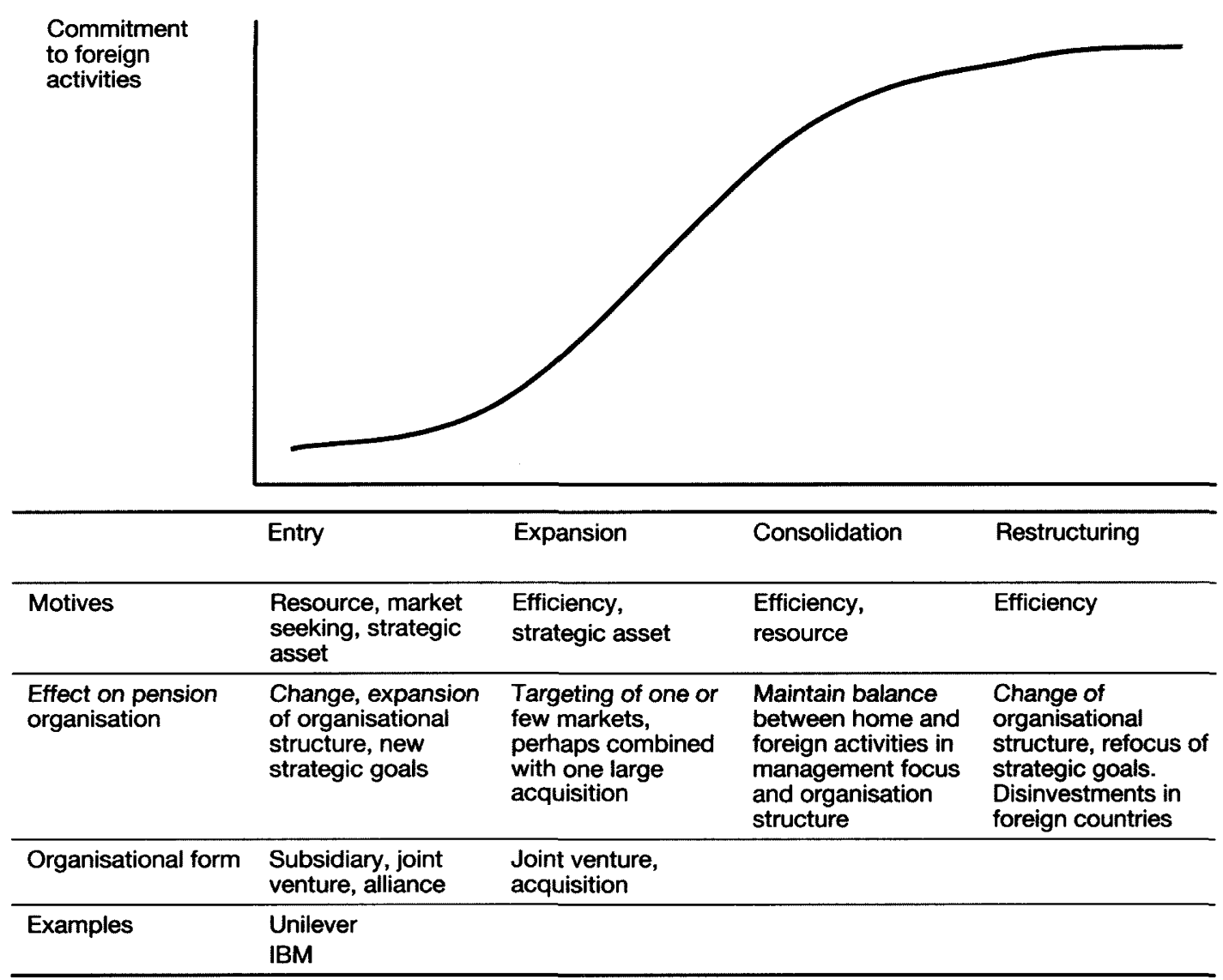

Figure 1 Stages of internationalisation

Source: adapted from Slager, 2004

where new pension markets emerge, such as in the Eastern European countries. Vested interests in existing institutional saving and pension schemes are lower (as well as the amounts saved), creating a broader receptiveness for new ideas and offering more opportunities for market seeking investments.

\section{The expansion phase}

In this phase, new products and market combinations are explored. Pensions are financial services, and therefore another home bias seems logical: the solidity of providing the financial service is closely linked to national attributes. Brand identity will play a far more important role in the EU countries: pension assets have been built up (representing a high vested interest), and/or countries have long-established financial institutions where a lot of trust is invested. Offering new products in other markets outside the home market will therefore either take shape through alliances, joint ventures or acquisitions, retaining the brand name of the foreign financial institution.

Further down the expansion phase, a number of the joint ventures or alliances in earlier stages form the basis for large mergers and acquisitions, when pension funds shift to an asset-seeking strategy. Other pension funds might be acquired, but it is likely that the front end organisation (such as brand name, customer organisation) remains intact, 
due to the built up brand identity.

Expected benefits from these

asset-seeking strategies will be upholding a market position when shifting from a domestic market position framework to a European pension market framework.

Also, cost synergies might be expected when integrating administrative and asset management functions.

The described phases are stylised, and several influences change their path of internationalisation. For example, current changes in accountancy rules make company funds less attractive and sector funds more attractive. The new rules require that the surpluses or deficits of a pension fund are integrated in the sponsor's balance sheet. Company pension fund results can easily overshadow those of the sponsor, but these rules cannot be applied to sector pension funds, which have a large number of sponsors.

These sector funds are very large in their own right and they are not constrained by special relationships with a single company. They may therefore well be the major drivers of internationalisation in the pension sector. Having a long investment horizon they are well placed to outperform banks and insurance companies. This in turn opens the possibility of profound rearrangements of power in the European financial sector.

\section{Concluding remarks}

It has been suggested that internationalisation patterns established in other research might be applicable to pension funds. It has further been observed that pension funds are currently in the entry stage. While this will be a permanent waiting chamber for the smaller pension funds, others will evolve their internationalisation strategy further.

The authors believe that the criteria for a successful internationalisation pattern has become more demanding. Internationalisation of pension funds can be interpreted as creating, in due course, a single global market for asset management and a single European market in pension fund services. Those that succeed will need access to capital resources to finance such strategies (fund management personnel, distribution, systems, technology, and new product research and development). They will also need a trustworthy brand name and long track records of successful international experience. A broad-based franchise is needed to weather the volatility that is a feature of international business. For asset management, the only alternative to tailoring products for the global market will be establishment as niche competitors in domestic markets. ${ }^{18}$

Several complicating factors form barriers to internationalisation though. Besides the earlier mentioned effect accountancy rules might have, another complicating factor is that a large number of European pension funds are state-governed. The transformation into a commercial or privatised organisation, as well as developing a strategic response to increasing internationalisation might be challenging for most organisations.

Nevertheless, the prospect of internationalisation carries in it the possibility of a period of reorganisation, restructuring and repositioning that has the potential to change the shape of financial markets.

\section{Note}

*Views expressed are those of the individual authors and do not necessarily reflect positions of PGGM. The authors are grateful to Yves Stevens and Lans Bovenberg for their helpful remarks on an earlier version of this paper.

\section{References}

1 Institutions for Occupational Retirement Provision.

2 Danner ECJ case C-136/00, 2002, Skandia ECJ case C-422/01, 2003 
3 'Deloitte are currently working with a number of clients including Unilever, one of the founding members of the original consortium, to implement pension pooling in practice', www.ipe.com/. See also Deloitte, 1 November 2004, 'Deloitte launches pension pooling offering', Press release, accessed on www.deloitte.com.

4 The chairman of the Dutch pension fund regulatory body PVK Dirk Witteveen admitted in the PVK's 2002 annual report that the body faced 'tensions in its supervision'. The PVK caused outrage in the Dutch pensions industry with a requirement that pension funds have a coverage ratio of at least 105 per cent: www.ipe.com/.

5 Berlinski, M. R. and Western, S. R. A. (1997), quoted in Davis, P. and Steil, B. (2001) 'Institutional Investors', The MIT Press, Cambridge, MA.

6 Slager, A. 'Banking Across Borders' (2004) Erasmus Research Institute for Management, Rotterdam.

7 Canals, J. (1997) 'Universal Banking' Oxford University Press, Oxford, UK.

8 Broby (1997) quoted in Davis, P. and Steil, B. (2001) 'Institutional Investors', The MIT Press, Cambridge, MA.

9 McKinsey (2003) 'Pan-European Asset Management Economics Survey 2002: Key Findings', McKinsey \& Company, available at www.mckinsey.de /_downloads/Presse/am_survey_slides_020117.pdf.

10 Kielholz, W.B. and Nebel, R. (2005) 'Improving regulatory governance', The Geneva Papers,
Vol. 20, pp. 34-42.

11 Heinemann, F., Schröder, M., Schler, M., Stirbck, C. and Westerheide, P. (2003) 'Towards a Single European Market in Asset Management', Zentrum für Europaische Wirtschaftsforschung, Mannheim, Germany.

12 Dunning, J. H. (1992) 'Multinational Enterprises and the Global Economy', Addison-Wesley, Wokingham, UK.

13 www.ing.com.

14 'For the majority of pension funds, in any case, this is hardly an issue: they are too small and inexperienced to contemplate investing abroad. But the 'big four', Commercial Union, ING's Nationale-Nederlanden, AIG and Poland's dominant insurer PZU, chafe at UNFE's restrictions. Together, they account for over 70 per cent of total pension-fund assets and have the global networks to target foreign stockmarkets.' See 'Patriotic pensions', The Economist, 30 August, 2001

15 Sundén, A. (2004) 'How do individual accounts work in the Swedish pension system?', Issue in Brief Vol. 5, No. 22. pp. 1-10.

16 Casey, B. H. (2004) 'Why People Don't Choose Private Pensions: The Impact of Contagion', Discussion Paper PI-0404, April, The Pensions Institute, London, UK.

17 Barber, T. (2005) 'Rome moves to block foreign takeovers of banks', Financial Times, 17 January, p. 6.

18 Davis, E. P. and Steil, B. (2001) 'Institutional Investors', The MIT Press, Cambridge, MA. 